\title{
Encouraging divergent thinking in HRM studies through use of project management case studies
}

Linda Twiname, Jenny Gibb

University of Waikato, New Zealand

\begin{abstract}
It is important that human resource management (HRM) undergraduate students develop critical thinking around project management decision making as part of their transferable skills development. Such initiatives provide opportunities for students to consider the implications of their decisions in relation to practical settings, that they might better address unexpected HRM demands of the future. We integrate project management into our teaching to progressively build students' skills in HRM. First, students engage in a project management case study and conduct a formal presentation. Second, we extend student awareness of divergent approaches to project management through engagement with excerpts from previous HRM student case studies. Third, the students execute project management of a written case study, under examination conditions. Our approach scaffolds students' higher order thinking and engagement with the divergent nature of the HRM discipline. We provide facilitator and student feedback to illustrate our outcomes. This research is relevant to management educators and, we suggest, is transferable to disciplines other than HRM.
\end{abstract}

Key words: higher order thinking, critical thinking, divergent thinking, project management

\section{Introduction}

All too often, management educators observe undergraduate students who are surface learners, primarily concerned with passing assessments. Research suggests (McLoughlin \& Luca 2002) that a deeper level of learning can be achieved when students take an active role in their learning. In this article, we present a practice project management case study process that engages students through a three-tier developmental teaching system (Falchikov 2005).

We accommodate for classroom diversity in our human resource management (HRM) teaching through a divergent project management education approach. In taking this approach, we provide students with realistic simulations that enable them to engage with the 'central concepts and principles' (Williams van Rooij 2009: 210) of the HRM discipline. As a consequence, students become more adept at assessing complex HRM situations and make better-informed judgements that they can justify. In so doing, students develop 'transferable and professional skills needed for project management' (McLoughlin \& Luca 2002: 572).

We develop project management case studies so that our students can explore divergent approaches to realworld HRM situations. Our approach aligns teaching, student development and assessment with industry and university requirements - while accommodating diversity (Biggs 2003: 141). Our students investigate 'real world problems' to develop their 'autonomy, independence, critical thinking, creativity and disciplined enquiry' (Tennant, McMullen \& Kaczynski 2010: 173), that they might better address unexpected HRM demands of the future. 


\section{Instigating project management and effective teaching}

Project management process skills are used in higher education teaching and learning across the world (Phelps, et al 2000). Such skills should be implemented so as to fully engage students, where a one-size-fits-all approach will not suffice. McLoughlin and Luca (2002: 576) suggest that project management provides opportunities for authentic task planning. We are particularly interested in its capacity to engage students in their learning, and to enhance their ability to make connections between theory and workplace relevant practice. In this section, we explore project management, higher order thinking and effective teaching and learning.

Through project management education, students gain independent learning skills. Ideally, educators will provide an appropriate level of scaffolding that is reduced as students' knowledge, skills and abilities are enhanced (William van Rooij 2009). Project management case studies are championed for their capacity to provide insights into practical situations (Williams van Rooij 2009) that enable learners to identify 'cause and effect, and help readers recognize the powerful influence of the context on behaviour' (Falchikov 2005: 8). Project management education provides opportunities for students to develop informed, creative, critical thinking, to articulate their arguments more effectively (Wang \& Wang 2011:210), and to develop transferable skills. As McLoughlin and Luca (2002: 577) argue, 'in the environment for project management, learners must defend the decisions they make in completing tasks, articulate plans with team members and defend the solutions and proposals that they make'.

Five criteria are said to be vital to project-based learning; they are outlined as follows.

The projects must be (a) central to the curriculum, (b) focused on questions or problems that drive learners to encounter and struggle with the central concepts and principles of a discipline, (c) a constructive investigation or goal-directed process that involves inquiry, knowledge building and resolution, (d) conducive to student autonomy, choice, unsupervised work time, and (e) realistic, focusing on authentic challenges where the solutions have the potential to be implemented (William van Rooij 2009: 210-211).

Project management activities of 'planning, organising, controlling and reporting' provide tertiary students with learning opportunities to engage in discrete, time-specific, goalorientated and stimulating real-world activities. When implemented responsively to student learning and discipline requirements, project management can facilitate student development (Phelps, Ledgerwood \& Bartlett 2000). It is ideally suited to online application (William van Rooij 2009). Most large higher education providers are using some online project management initiatives in their courses (Abdous \& He 2008). However, project management is not without cultural and staff development challenges. Therefore, the application of project management should be continually monitored and refined to meet organisational, student and staff capacities (Phelps, Ledgerwood \& Bartlett 2000).

We advocate teaching strategies that engender a pedagogy of learning and discovery (Tennant, McMullen \& Kaczynski 2010: 173) to develop a learning climate (Biggs 2003: 64) that creates and sustains student motivation (Biggs 2003: 61) and higher order thinking. Higher order thinking is exhibited through informed judgement, planning and the capacity to consider multiple perspectives as a part of decisionmaking (Wang \& Wang 2011: 212). 
Higher order thinking is facilitated through critical thinking, including 'making judgments, generating ideas, exploring consequences, reviewing options, monitoring progress ... reflective thinking, integrative thinking, and deep thinking' cognitive processes (Wang \& Wang 2011: 208). It is suggested that 'students must develop thinking skills in all higher order thinking aspects in order to meet the challenges of the fast changing world' (Wang \& Wang 2011:213). We suggest project management is a useful approach to facilitate that process.

Higher order thinking is developed through critical thinking and self assessment. In a teaching arena, critical thinking is illustrated through students' capacity to consider the implications of their decisions, to explain their arguments clearly, to support them through reference to pertinent factors, including the social context. Critical engagement 'is a rational reflection on one's own and others' ideas in order to get a clearer understanding of an issue' (Bak 2003). To embed student learning through their project management activities, we provide opportunity for self-assessment and reflection. Collaboration and group work through practice case studies enable 'self-reflection and joint construction of knowledge' ( $\mathrm{Du}$, et al, 2005: 13). Self-assessment can be emancipating as 'it contributes to the development of ... students' self-knowledge and self-understanding' (Boud 1995: 20).

Our challenge as educators is to create an environment that encourages students to move outside their comfort zone so that they can develop and apply new knowledge. Thinking is encouraged when the processes that enhance it are 'explicit rather than implicit' (BeharHorenstein \& Niu 2011: 36). Students should not have to second-guess what might be assessed (Falchikov 2005: 37). When students know what they can do and how to go about it (Biggs 2003: 59), they will be motivated to achieve and will expect success (p. 56). A divergent approach enables a level of risk taking as it recognises 'many possible answers' (Falchikov 2005: 7). We encourage students' critical thinking and rely on their 'creativity and interpretation' to identify and defend their interpretations of the factors that impact upon situations as presented in a case study (Falchikov 2005: 7).

Teaching environments that enable students to request additional information as a part of the learning simulation enable another dimension of realism (Falchikov 2005: 8-9) and learning. Through the use of case studies, and the availability of additional information, assessors can align assessment practices with activities that take place in real workplace settings - as distinct from the often artificial constructs of university courses. This informs and improves both student and assessor judgement, while meeting their respective requirements (Boud \& Falchikov 2007: 23), through formative (identification of capacity for improvement) and summative (judgement/diagnosis of present position) assessment processes (Falchikov 2005: $3)$.

Diversity within groups can be accommodated (and classified) through a three-tier, cumulative, developmental system as identified by Habermas (Falchikov 2005) and further developed through action research as described by Kemmis (2001), who proposes that there are three distinct approaches i) technical or instrumental, ii) practical, and iii) emancipatory. Each enables identification of differing developmental achievements, or sets of objectives, which students/participants hold. The distinctions Kemmis makes offer useful diagnostic instruments through which teachers (and students) can assess a range of goals and achievements (learning outcomes), from achieving functional improvements to more emancipatory goals. 
[1] a technical or instrumental (or means-ends) interest in the case of empirical - analytic research — that is, an interest in getting things done effectively; [2] a practical interest in the case of interpretive research - that is, an interest in wise and prudent decision-making in practical situations; [3] and an emancipatory interest in the case of critical research - that is, an interest in emancipating people from determination by habit, custom, illusion and coercion which sometimes frame and constrain social and educational practice, and which sometimes produce effects contrary to those expected or desired by participants and other parties interested in or affected by particular social or educational practices (Kemmis 2001: 92, emphasis in original).

Also referred to as Brew's typology, Falchikov highlights the system's capacity to 'enable us to classify self and peer assessment studies according to the level of student involvement' (2005: 128). The distinctions provide a heuristic device through which we can compare teaching approaches and outcomes. Therefore, we use them to assess the effectiveness of the practice case study presented here.

We implemented a project management case study process in our HRM teaching program. We designed it to facilitate our students' learning about, and engagement with, the technical, practical and potentially emancipatory elements of our discipline. Our overarching goal is to align our teaching, student development and assessment towards industry and university requirements and, of course, to enhance our students' learning.

\section{The context for project management education practice case study}

The context for our practice case study exercise is a third-year undergraduate HRM course that is offered at the University of Waikato, in Hamilton, New Zealand. The students are required to study organisational behaviour before this class. Some have work experience in HRM but, as a rule, this is their first introduction to studying HRM in a tertiary institution. We developed a project management case study process that we integrate throughout the teaching period, building towards the final examination and work life (an outline is provided in Appendix A). Through the use of practice case studies, we work to develop our students' higher order thinking through project management decisionmaking.

The project management case study process described here is integrated into a 12-week semester of teaching, which is followed by a two-hour examination. It has run in three iterations between 2010 and 2011 with 42, 37 and 67 students. On average, 44\% of students are completing a bachelor of management studies degree, $30 \%$ are completing a bachelor of social science degree, $18 \%$ are completing a graduate degree and $8 \%$ are completing a range of management diplomas. Usually $50 \%$ to $80 \%$ of the students are female. About $74 \%$ of our students are New Zealanders, with the remaining $26 \%$ overseas students or permanent residents.

\section{Method}

Each semester, we develop a project management case study for our HRM students' end of semester examination summative assessment, for which they are required to answer questions in essay form. The examination is conducted through a formal process in accordance with our universities' requirements. In each case, we either develop entirely new cases, or modify existing ones to incorporate contemporary and contextual HRM issues. Recent past examination cases are used during the semester as project management cases (an example is 
provided in Appendix B). Our approach recognises students' concerns about assessment. It aligns teaching, student development and assessment towards industry and university requirements. It also makes better use of the time that we devote to developing project management practice case studies for examination purposes, as these cases now form part of the body of future teaching.

During the semester, students are asked to imagine that they are HRM consultants working on a project-based learning management scenario, which we provide. They are required to critically reflect upon the case in the light of HRM, organisational, industry and contextual factors, and make recommendations in response to our project management questions, which they are expected to justify. The case study is based on a real, contemporary situation set in our local context ${ }^{1}$. Students have opportunities to practice, research, collaborate, make a formal presentation, learn from others' work and reflect upon their learning.

Overall, our approach is designed to develop students' skills and potential as follows: Technical skills - clarifying assessment requirements and expectations (reducing the need to second-guess), researching, collaborating and exploring summative formal examination writing skills;

Practical skills - applying HRM knowledge, engaging in project management, developing through formative assessment learning and communicating - online, interpersonally and in writing;

Emancipatory potential — higher order thinking, critical thinking and divergent thinking.

We conduct our practice case study over several weeks, through a combination of in-class and online engagements which we outline next.

\section{Task 1: A practice case study to develop project management skills}

A group of students is allocated a past examination project management case and its requirements, about which they do research, decide on an approach, write a group report, formally present to their class and lead a class discussion. Students work online to communicate and coordinate their project where they: 1) use appropriate HRM literature to analyse the case in association with organisational/contextual factors; 2) present their analysis to their tutorial group; and 3) write a referenced group report.

\section{Task 2: Project management preparation based on excerpts from previous students' examination scripts to illustrate the divergent nature of HRM}

Later in the semester, after the group presentations, we revisit the project management case. To illustrate the divergent nature of the cases, we lead a class discussion and co-produce a list of potential approaches for each of the required case questions (an example is provided in Appendix C). We then use excerpts from past examination scripts during in-class teaching, ${ }^{2}$ and focus on conclusion writing. Conclusion writing is an area that students find challenging. We have found that it reflects student case study analysis skill levels, and is hence worthy of attention. Next, we distribute copies of the practice case study, examination questions and sample examination scripts. Students work in groups to analyse and prioritise case issues in relation to contextual factors. During this time they are encouraged to go online and research the project further as they develop their responses. At an appropriate time, the groups of

\footnotetext{
${ }^{1} \mathrm{NB}$ : The in class simulation exercise we use each semester are different as they are based upon the previous semesters examination case study. While the individual cases vary their structure and testing principles are similar. Taking this approach enables us to refine the scenarios in response to student and staff feedback. It also reduces student plagiarism.

${ }^{2}$ We have gained formal ethics, and student, approval to show excerpts from the past examination paper under discussion.
} 
students are asked to draw together their reading, analyses and discussions into a written concluding paragraph based on the aforementioned material - i.e., as members of a project group assigned a practice case study. Next, the groups post their concluding paragraphs through an intranet system that is available to students and staff. Finally, all students are invited to critique and enhance the posted concluding paragraphs.

\section{Task 3: We distribute the case study for the students' formal final examination (but not the examination questions)}

At the last lecture of the semester we distribute the case study for the students' upcoming examination. The case is printed on bright coloured paper. Students are advised that they can research the case and write on the page, and that they can take it into the examination (to be held at a later date). The handout does not include the examination questions. Sufficient material is provided so that the students have a reasonable idea of the nuances of the examination, but not its detail or direction.

\section{Student feedback}

We sought student feedback on our initiative through two sources - a questionnaire and through analysis of their examination scripts. We administered a short questionnaire at the end of the tutorial where we conducted Task 2 (project management preparation based on excerpts from previous students' examination scripts to illustrate the divergent nature of HRM). Our students indicated our practice case studies reinforced their learning. Next, we provide quotations that reflect students' perspectives. They indicate the effectiveness of our project management case study process. We use Brew's typology to classify them under our key performance indicators 'according to the level of student involvement' (Falchikov 2005: 128) as follows:

Technical skills - clarifying assessment requirements and expectations (reducing the need to second-guess), researching, collaborating and exploring summative formal examination writing skills;

- 'I have a clear idea of what the [examination] questions require'

- ' $[\mathrm{I}$ know $]$ about the format of essay writing and what is expected in the exam'

- 'Yes I have an idea [of] what is expected'

Practical skills - applying HRM knowledge, engaging in project management, developing through formative assessment learning and communicating — online, interpersonally and in writing;

- 'It was really good [at] developing skills'

- 'It reinforced what we learnt'

Emancipatory potential - higher order thinking, critical thinking and divergent thinking.

- 'Through case studies I can learn and improve'

- 'There are many different but still correct ways to answer an exam question'

Examination scripts provided further insight into student development. We observed that the quality of students thinking and arguments has been enhanced. We consider this to be a key indicator of our success. We noticed that, in comparison to a typical examination setting, these students were calm before they went into the examination room. They were quietly confident, and ready for their 'race'. 


\section{Discussion}

We have found our project management exercise process provides an effective approach to enhancing student learning and awareness. In using this method, we are able to encourage students to consider multiple perspectives as part of HRM decisionmaking. Five criteria are argued to be vital to project-based learning (William van Rooij 2009: 210-211). These five criteria are discussed below in the context of our project management practice case study process.

(a) Central to the curriculum.

Practice case studies are central to our curriculum and assessment. A recent past examination is used for teaching purposes and to prepare students for a major assessment (Appendix A). Through class and online student interaction we work to create practical learning environments that motivate higher order thinking. Students are encouraged to think critically, creatively and independently regarding a case, while reflecting upon core HRM concepts.

(b) Focused on questions or problems that drive learners to encounter and struggle with the central concepts and principles of a discipline.

Our practice case studies provide a range of information that can be viewed, justifiably, from different perspectives (Appendix B). In all stages of the work presented here - including the examination - students are encouraged to conduct further research. From a potentially limitless range of information, students are required to make decisions to address questions or problems concerning the case and to argue in their defence. Thus, the practice case study creates a situation similar to HRM practice.

Self-knowledge and self-understanding are central to the HRM discipline, where balanced judgement and wise decisionmaking is required. It is argued that self-assessment can be emancipating, as 'it contributes to the development of a person' (Boud 1995: 20). Therefore, opportunities for self-assessment are provided to enhance 'students' self knowledge and self understanding' (Boud 1995: 20). Skills development and self-assessment are enabled through group work, where students debate, and articulate skills and processes (Boud 1995: 18-19).

\section{(c) A constructive investigation or goal-directed process that involves enquiry, knowledge- building and resolution.}

We suggest that, as educators, our challenge is to create learning environments that motivate learning and discovery - ideally higher order thinking — through a range of approaches including independent and group work. We work to develop contexts where students can safely learn by doing, including from making errors. The teaching learning activity described here presents students with scenarios that they must investigate, recommend solutions for and be able to defend.

Through our real-world project management practice case study processes, students are required to research and consult in order to enhance their knowledge. For example, we provide students with the examination case before the examination and allow them to take notes into the examination room. This process enables students to make more sophisticated decisions regarding a given situation - to think critically and reflect upon different potential approaches, and to consider their potential outcomes. We suggest our approach to the examination extends student learning, provides a truer test of student abilities and a more realistic simulation of project management. 
(d) Conducive to student autonomy, choice, unsupervised work time.

Our practice case study scenarios enable students to work alone, online or in teams, as they critically evaluate and consider a broad range of potential factors and approaches (examples provided in Appendix B), along with their expected and unexpected consequences. Students work unsupervised as they decide for themselves the 'best' approaches to scenarios we pose.

(e) Realistic, focusing on authentic challenges where the solutions have the potential to be implemented.

'Authentic' participation is argued to be a necessary aspect of liberation processes. We have chosen a participatory teaching process that engages students to become actively involved in the enhancement of their learning experiences. Our practice case studies provide students with exposure to HRM situations where they must make decisions, but also where they must consider contemporary contextual factors that impact on workplace decisions and practice.

By taking a divergent approach, we provide students with authentic challenges as they decide on and justify the approaches they recommend for implementation. As we discussed earlier, divergent tests have 'many possible answers' (Falchikov 2005: 7). We rely on 'the creativity and interpretation of the testee' (our students) to identify and defend their answers (Falchikov 2005: 7). Such an approach can be new and challenging for students who are less cognitively developed; their initial assumed approach appears to lean towards surface learning. It seems that (some of) our educational systems reward students for memorising and regurgitating material. That approach does not fit with the HRM discipline or the skills we seek to develop through project management. Embedded in our approach is a commitment to making the implicit explicit - i.e., enabling students to see some of the approaches that could be taken in addressing a practice case study and clarifying expectations. Through our real-world project management practice case study processes, we work to enhance student learning at a deeper level, by scaffolding their initial learning through the practices described here.

\section{Conclusion}

We believe the project management case studies that we have developed prepare students for real-world project management and generally enhances their learning outcomes. The process also enables them to self-assess as they work together. Our claims are supported through student feedback, the calm way they approach their examinations and the quality of their examination scripts. Overall, the project builds students' HRM project management, group work and online skills, while extending their capacity to critically reflect on diverse approaches to project management scenarios.

\section{References}

Abdolus, M. \& He. W. 2008, Streamlining the online course development process by using project management tools. The Quarterly Review of Distance Education vol. 9, no. 2, 181-188.

Bak, N. 2003, Guide to academic writing, University of the Western Cape, http://www.uwc.ac.za/students/postgraduates/downloads/ACADEMIC $\% 20$ WRITING $\% 20$ GUIDE $\% 20$ -\%20complete $\% 20$ draft.doc.

Behar-Horenstein, L.S. \& Niu, L. 2011, Teaching critical thinking skills in higher education: a review of the literature, Journal of College Teaching and Learning, vol. 8, no. 2, 25-41.

Biggs, J. 2003, Teaching for quality learning at university, sec. ed., McGraw-Hill Education, Berkshire, UK.

Boud, D. 1995, Enhancing learning through self assessment, Kogan Page, London.

Boyd, D. \& Falchikov, N. 2007, Rethinking assessment in higher education: learning for the longer term, Routledge, London.

Du, J., Havard, B., Adams, J. \& Li, H. 2005, A project-based learning approach: online group collaborative learning, International Journal of Information and Communication Technology Education, Vol. 1, no. 4, 13-24, Oct-Dec. 
Falchikov, N. 2005, Improving assessment through student involvement: practical solutions for aiding learning in higher and further education, RoutledgeFlamer, London.

Kemmis, S. 2001, Exploring the relevance of critical theory for action research: emancipatory action research in the footsteps of Jurgen Habermas, Handbook of action research: participative inquiry and practice, Reason, P. \& Bradbury, H. (eds), Sage, London.

McLoughlin, C \& Luca J. 2002, A learner-centred aproach to developing team skills through web-based learning and assessment, British Journal of Educational Technology, vol. 33, no. 5, 571-582.

Nkomo, S. M., Fottler, M.D. \& McAfee, R.B. 2008, Human resource management applications: cases, exercises, incidents and skill builders, 6th ed., Case 102 Selecting a manager for a Nigerian facility, Thomson South Western, USA (case modified for examinations purposes).

Phelps, R., Ledgerwood, T. \& Bartlett, L. 2000, Managing the transition to online teaching: the role of project management methodology in the learning organisation, Southern Cross University ePublications@SCU.

Tennant, M. McMullen, C. \& Kaczynski, D. 2010, Teaching, learning and research in higher education, Routledge, London.

Wang, S. \& Wang, H. 2011, Teaching higher order thinking in the introductory MIS course: a model-directed approach, Journal of Education for Business, vol. 86, 208-213.

Williams van Rooij, S. 2009, Scaffolding project-based learning with the project management body of knowledge (PMBOK), Computers and Education, DOI 10.1016/j.compedu.2008.07.012.

\section{About the authors:}

Dr Linda Twiname is a Senior Lecturer in the Department of Strategy and HRM, Waikato Management School, the University of Waikato, New Zealand. Her research explores the human dimension of HRM studies, endorsing sustainable management systems that value interpersonal relationships as key contributors to organisational overall success - both social and financial. She has a particular interest in critical examinations of power relationships within societies and within organisations. Her PhD thesis was titled "In search of wellbeing in the workplace: exploring the emancipatory potential of participatory sction research". Her research contributes to the body of knowledge on participatory action research to facilitate organisational change; and the application of Habermas's concepts of the life world, communicative action, the system and instrumental action. She supports critical analysis of organisational practices including: workplace wellbeing, social responsibility, conflict management, work-life balance, EEO, ethical practices, workplace values, and generally how we might become employers of choice.

Email: lindat@waikato.ac.nz

Dr Jenny Gibb is a Senior Lecturer in the Department of Strategy and HRM Management, Waikato Management School, University of Waikato, New Zealand. Her research takes a socioeconomic perspective in examining the interrelationships between individual, firm and network performance. She has published on value creation opportunities via the adoption of information technologies, particularly in electronic networks. She also has a strong pedagogical interest where her focus has been on e-learning and information technologies, including working in virtual teams. Her other area of interest focuses on the micro-foundations of competitive advantage. In particular, she is interested in understanding the foundations of firm-level competitive actions. This includes understanding how key decisionmakers within firms set and adjust their goals that shape these actions. It also includes identifying and explaining how the actions taken by individuals and groups at a microlevel relate to the goals and, ultimately, the firm's performance and competitiveness. 
Appendix A: Overview of the project management education process ${ }^{3}$

\begin{tabular}{|c|c|c|c|c|}
\hline Weeks & Topics & Activities & Scaffolding & Key learning outcomes \\
\hline $1 \rightarrow 2$ & $\begin{array}{l}\text { Introduction to } \\
\text { the nature of } \\
\text { HRM }\end{array}$ & $\begin{array}{l}\text { Interpersonal } \\
\text { introductions } \\
\text { Outline of teaching and } \\
\text { assessment methods } \\
\text { Tips on presentations } \\
\text { Analysis of interviews, } \\
\text { and critique against } \\
\text { literature }\end{array}$ & $\begin{array}{l}\text { Individual and group work that } \\
\text { illustrates the diversity within the } \\
\text { HRM discipline } \\
\text { Clear expectations and practices } \\
\text { Detailed feedback provided } \\
\text { quickly and regularly } \\
\text { Work discussed in groups } \\
\text { IT and HRM support available } \\
\text { online } 24 / 7\end{array}$ & $\begin{array}{l}\text { Developing knowledge of HRM } \\
\text { and awareness of required skills } \\
\text { Understanding what is required } \\
\text { Building self-confidence and } \\
\text { confidence in teams } \\
\text { Enhanced communication skills } \\
\text { Opportunities to self-assess }\end{array}$ \\
\hline $3 \rightarrow 4$ & $\begin{array}{l}\text { Contextual } \\
\text { HRM }\end{array}$ & $\begin{array}{l}\text { Introduction to project } \\
\text { management through case } \\
\text { studies } \\
\text { Practice interviewing } \\
\text { Ongoing other assessment }\end{array}$ & $\begin{array}{l}\text { In-class group work to explore, } \\
\text { discuss and reflect upon practice } \\
\text { case studies } \\
\text { Independent and group work, } \\
\text { online and in person }\end{array}$ & $\begin{array}{l}\text { Joint construction of knowledge } \\
\text { Insight into the complexities of } \\
\text { HRM } \\
\text { Further development of skills }\end{array}$ \\
\hline $5 \rightarrow 11$ & $\begin{array}{l}\text { HRM in } \\
\text { practice }\end{array}$ & $\begin{array}{l}\text { Student presentations } \\
\text { including the Washington } \\
\text { Mining practice case } \\
\text { study } \\
\text { Ongoing other assessment }\end{array}$ & $\begin{array}{l}\text { Support from staff before and } \\
\text { during presentations (as } \\
\text { appropriate and requested) } \\
\text { Student-led exploration of past } \\
\text { examination practice case studies } \\
\text { and divergent approaches to them }\end{array}$ & $\begin{array}{l}\text { Insight into the divergent nature } \\
\text { of HRM } \\
\text { Depending upon individual } \\
\text { developmental stage, skills in: } \\
\text { assessment, analysis, } \\
\text { interpretation, planning, } \\
\text { preparation, production, } \\
\text { coordination, facilitation and } \\
\text { presentation (written and oral) of } \\
\text { project management case studies }\end{array}$ \\
\hline 12 & $\begin{array}{l}\text { Examination } \\
\text { cases: past and } \\
\text { present }\end{array}$ & $\begin{array}{l}\text { Review of teaching and } \\
\text { examination tips } \\
\text { Study of examination } \\
\text { script examples } \\
\text { Examination case } \\
\text { distributed (questions } \\
\text { withheld) }\end{array}$ & $\begin{array}{l}\text { An overview of HRM subject } \\
\text { matter covered } \\
\text { In-class and online group work, to } \\
\text { read, analyse and discuss material } \\
\text { in order to write a concluding } \\
\text { paragraph that illustrates the level } \\
\text { of understanding and skill }\end{array}$ & $\begin{array}{l}\text { Reduces the need to second- } \\
\text { guess the examination } \\
\text { Enhanced insight into the } \\
\text { divergent nature of HRM and its } \\
\text { application in practice } \\
\text { Confidence to express own ideas } \\
\text { online with a critical audience }\end{array}$ \\
\hline
\end{tabular}

\footnotetext{
${ }^{3}$ We also provided other learning opportunities for our students. This paper focuses on the project management education through practice case study components of the teaching, learning and assessment.
} 
Appendix B: A past examination practice case study

Q.1 Read the attached 'Selecting a manager for a Washington Mining Co.' case and detail regarding the three candidates. Answer the questions below in essay format (50 marks).

a. Would it be best for Washington Mining Co. to select a manager who is a local (New Zealander); a home country national (citizen of the USA); or a third-country national (citizen of a country other than New Zealand or USA)?

b. Which of the factors to be considered would favour the selection of Toni Smith, Zachariah Hashim or Robin Brown?

c. Which candidate do you recommend the firm to employ? Why?

\section{Selecting a Manager for Washington Mining Co.}

Washington Mining Co. is a supplier of drilling equipment for gold exploration. It is headquartered near Houston, Texas. The company has seven offices and warehousing facilities near potential markets for its equipment. Only 30 percent of Washington's profits come from selling equipment; the rest comes from leasing. Within its leasing operations, half the profit comes from supplying operators for the equipment. Washington has over 25 years of experience in Texas and Louisiana, and 10 years of experience in Australian and Malaysia. Most of the customers are large multinational gold bullion companies. However, approximately 20 percent of its contracts are with small, independent exploration companies. Washington has just completed construction of a new facility near Thames on the Coromandel Peninsula — its first venture into New Zealand. The machinery, trucks and equipment to operate this facility are to arrive within the next three months. You are the assistant human resource officer for Washington, and you have been instructed to review the records of the three leading candidates for manager of this new facility. You must recommend one of the three to your boss, the human resources director.

Before you examine the records, you make a list of factors that you believe should be taken into consideration:

1. General criteria: education, experience, job knowledge, desire and stability.

2. The New Zealand facility will be in the startup phase.

3. Washington wants to develop some of its current managers in international operations.

4. Few New Zealanders have experience in the technical aspects of mining for the gold, yet Washington has built its reputation on the expertise of its managers and customer acceptance of its managers as knowledgeable professionals.

5. Although some of Washington's managers have had experience in the South Pacific (Australia), none have had experience in New Zealand.

6. Political power within the New Zealand government shifts periodically; there is local disquiet regarding increased mining in the Coromandel; and many of those with whom Washington negotiated its move into New Zealand are no longer in positions of power.

7. The supply of trained gold-mining equipment operators in New Zealand is much less than the demand.

The three candidates are:

Toni Smith: Age 34, is a citizen of the United States of America (USA) and graduated from St. Mary University with a Bachelors degree from the Bill Greehey School of Business. In ten years of employment at Washington Mining Co. Toni's record has been outstanding, it is often said that, some day, Toni will be president of Washington Mining Co. Toni has never been out of the USA.

Zachariah Hashim: Age 52, is a Malaysia citizen, who was educated in England. Zachariah has been with Washington Mining Co. for 21 years and has been promoted over time within the organisation. Zachariah spent two years in company headquarters planning operations and is well respected throughout the company. Zachariah currently manages Washington Mining Co. facility in Australia.

Robin Brown: Age 46, a New Zealand citizen, graduated from Waikato University with Bachelors in Management Studies, and served three years in the Army. Robin is the owner/manager of the largest Honda dealership in New Zealand, and is keen to take on new challenges, but has had no experience with mining equipment (Nkomo, Fottler, \& McAfee, 2008, case modified for examinations purposes). 


\section{Appendix C: An illustration of potential divergent thinking}

The following are examples of potential approaches for each of the required questions within the examination case essay 'Selecting a Manager for Washington Mining Co'. We do not suggest this is a conclusive list. But it does illustrate the divergent design of the examination case questions.

\section{The first question:}

'Would it be best for Washington Mining Co. to select a manager who is a local (New Zealander); a home country national (citizen of the USA); or a third-country national (citizen of a country other than New Zealand or USA)?'

This question could be addressed through discussions around some of the following factors:

- Organisational criteria,

- Recognition that NZ operation is in a startup stage of organisation,

- Focus on the international nature of the business,

- Applicants technical skills,

- Cultural issues within organisations and countries - efforts to establish/maintain harmony,

- Supply of appropriate skills,

- The impact of the political context(s),

- Environmental concerns and staff capacity to address/minimise them,

- Overall organisation and staff development strategies (promotion \& staff development from within).

\section{The second case question:}

'Which of the factors to be considered would favour the selection of Toni Smith, Zachariah Hashim or Robin Brown?'

This question could be considered through discussion around some of the following factors:

Evaluation of the applicants' experience,

- The applicants (perceived) knowledge, skills and abilities,

- The applicants' fit to the organisation, its culture and goals,

- And more.

\section{The third case question:}

'Which candidate do you recommend the firm to employ? Why?'

This question could be addressed through the following justifications:

- Referral to the 'big picture' contextual factors,

- Strategic staff development,

- Holistic thinking,

- Staff development and learning within the larger organisation structure,

- Utilisation of alliances within the organisation and local area. 